\title{
Presence and regulation of messenger ribonucleic acids encoding components of the class II major histocompatibility complex-associated antigen processing pathway in the bovine corpus luteum
}

\author{
Matthew J Cannon, John S Davis ${ }^{1}$ and Joy L Pate \\ Department of Animal Sciences, The Ohio State University/Ohio Agricultural Research and Development Center, \\ 1680 Madison Avenue, Wooster, Ohio 44691, USA and ${ }^{1}$ Olson Center for Women's Health, Department of \\ Obstetrics and Gynecology, University of Nebraska Medical Center, Omaha, Nebraska 68198, USA and Veterans \\ Affairs Medical Center, Omaha, Nebraska, 68105, USA
}

Correspondence should be addressed to J L Pate; Email: pate.1@osu.edu

\begin{abstract}
Luteal cells express class II major histocompatibility complex (MHC) molecules and can stimulate T lymphocyte proliferation in vitro. However, it is unknown whether luteal cells express the intracellular components necessary to process the peptides presented by class II MHC molecules. The objective of the present study was to examine the expression and regulation of three major class II-associated antigen processing components - class II MHC-associated invariant chain (Ii), DM $\alpha$ and DM $\beta$ - in luteal tissue. Corpora lutea were collected early in the estrous cycle, during midcycle and late in the estrous cycle, and at various times following administration of a luteolytic dose of prostaglandin $\mathrm{F}_{2 \alpha}\left(\mathrm{PGF}_{2 \alpha}\right)$ to the cow. Northern analysis revealed the presence of mRNA encoding each of the class II MHC-associated antigen processing proteins in luteal tissue. li mRNA concentrations did not change during the estrous cycle, whereas DM $\alpha$ and DM $\beta$ mRNA concentrations were highest in midcycle luteal tissue compared with either early or late luteal tissue. Tumor necrosis factor- $\alpha$ (TNF- $\alpha$ ) reduced DM $\alpha$ mRNA concentrations in cultured luteal cells in the presence of $\mathrm{LH}$ or $\mathrm{PGF}_{2 \alpha}$. DM $\alpha$ and DM $\beta$ mRNA were also present in highly enriched cultures of luteal endothelial (CLENDO) cells, and DM $\alpha$ mRNA concentrations were greater in CLENDO cultures compared with mixed luteal cell cultures. Expression of invariant chain, DM $\alpha$ and DM $\beta$ genes indicates that cells within the corpus luteum express the minimal requirements to act as functional antigen-presenting cells, and the observation that CLENDO cells are a source of DM $\alpha$ and DM $\beta$ mRNA indicates that non-immune cells within the corpus luteum may function as antigen-presenting cells.

Reproduction (2006) 131 689-698
\end{abstract}

\section{Introduction}

Luteal regression is a complex cascade of events, initiated by prostaglandin $F_{2 \alpha}\left(P F_{2 \alpha}\right)$, that causes cessation of luteal function and subsequent structural demise of the corpus luteum (CL). Several lines of evidence suggest participation of the immune system in this process. Macrophages and $\mathrm{T}$ lymphocytes are present in the $\mathrm{CL}$ of several species, and infiltrate the $\mathrm{CL}$ near the time of luteal regression and in response to $\mathrm{PGF}_{2 \alpha}$ (Bagavandoss et al. 1990, Brännström et al. 1994, Lawler et al. 1999, Penny et al. 1999, Krusche et al. 2002, Townson et al. 2002, Komatsu et al. 2003, Neuvians et al. 2004). Cytokines produced by these cells - including tumor necrosis factor (TNF)- $\alpha$, interferon (IFN)- $\gamma$, interleukin (IL)-1 $\beta$ and
IL-6 - decrease progesterone production, increase prostaglandin synthesis and stimulate apoptotic death in cultured luteal cells (Nothnick \& Pate 1990, Fairchild \& Pate 1991, Benyo \& Pate 1992, Gorospe et al. 1992, Townson \& Pate 1994, 1996, Jo et al. 1995, Del Vecchio \& Sutherland 1997, Young et al. 1997, Petroff et al. 2001). The presence of these cytokines has been detected in luteal tissue (Bagavandoss et al. 1990, Ji et al. 1991, Penny et al. 1999, Petroff et al. 1999, Krusche et al. 2002, Townson et al. 2002, Komatsu et al. 2003, Neuvians et al. 2004), indicating that macrophages and T cells present within the $\mathrm{CL}$ are activated. Class II major histocompatibility complex (MHC) molecules are also expressed by luteal cells of several species (Khoury \& Marshall 1990, Benyo et al. 1991, Kenny et al. 1991, Penny et al. 1999), 
providing a means of activation of $\mathrm{T}$ lymphocytes present in luteal tissue.

Class II MHC molecules, which are typically expressed on antigen-presenting cells of the immune system (i.e. macrophages, dendritic cells and B lymphocytes), present small peptides processed intracellularly to $T$ lymphocytes (Sant 1994). When cells expressing class II MHC molecules (antigen-presenting cells) interact with $\mathrm{T}$ cells, the peptides bound to the MHC molecules determine whether the antigen-presenting cell will activate $\mathrm{T}$ cells. The immune system is tolerant of normally expressed self-peptides, but T lymphocytes can be activated by cells expressing peptides derived from a foreign source (i.e. viral or bacterial peptides) as well as self-peptides that are presented by MHC molecules under abnormal conditions (i.e. tumor antigens). As class II MHC molecules are synthesized, they immediately bind to a chaperone protein called invariant chain (li), a portion of which occupies the peptide-binding groove of the MHC molecule (Roche \& Cresswell 1990, Avva \& Cresswell 1994). Invariant chain serves a dual function, directing intracellular transport of class II MHC molecules (Bakke \& Dobberstein 1990, Lotteau et al. 1990) and ensuring that binding of 'inappropriate' peptides does not occur prematurely (Roche \& Cresswell 1990). Class II MHC-li complexes are transported into specialized intracellular compartments in which proteases degrade the Ii into a peptide called class II-associated invariant chain peptide (CLIP) (Maric et al. 1994, Riese et al. 1996). Prior to binding of antigenic peptides by class II MHC molecules, the CLIP fragment bound to the peptide binding groove must be removed. Removal of CLIP is carried out by a class II MHC-like heterodimeric protein referred to as DM (Fling et al. 1994, Morris et al. 1994). Following CLIP removal, DM stabilizes class II MHC molecules to allow efficient binding of antigenic peptides (Denzin et al. 1996).

In addition to the primary roles for li and DM described above, these intracellular proteins have been implicated in a secondary role as 'editors' of the repertoire of peptides presented to T cells in the context of class II MHC, since they control in part the type of peptides that bind to class II MHC molecules and that are presented to T lymphocytes (Castellino et al. 1997, Vogt et al. 1999). Antigen-presenting cells taken from li or DM knockout animals stimulate activation and proliferation of otherwise non-reactive $\mathrm{T}$ cell clones and reveal the presence of 'self-reactive' $\mathrm{T}$ cells in normal animals (Bodmer et al. 1994, Katz et al. 1996, Marieke van Ham et al. 1996, Lightstone et al. 1997), indicating that alterations in li or DM expression may alter the ability of antigen-presenting cells to stimulate $\mathrm{T}$ cell activation.

Expression of class II MHC molecules is not limited to cells of the immune system, and in many cases expression of class II MHC molecules by other cell types is associated with inflammation and/or autoimmune disorders. Cells of the bovine $\mathrm{CL}$ express class II MHC molecules, and class II MHC expression increases near the end of the estrous cycle and in response to a luteolytic dose of $\mathrm{PGF}_{2 \alpha}$ (Benyo et al. 1991). Bovine luteal cells also stimulate class II MHC-dependent in vitro proliferation of $\mathrm{T}$ cells isolated from the same animal (autologous T cells) (Petroff et al. 1997). Following administration of a luteolytic dose of $\mathrm{PGF}_{2 \alpha}$ to the cow, the ability of luteal cells to stimulate $\mathrm{T}$ lymphocyte proliferation is enhanced (Petroff et al. 1997). The enhancement of luteal cell-stimulated T lymphocyte proliferation may be due at least in part to the effect of $\mathrm{PGF}_{2 \alpha}$ on progesterone synthesis in vitro (Cannon et al. 2003), which decreases following in vivo exposure to $\mathrm{PGF}_{2 \alpha}$ (Pate \& Nephew 1988). However, we speculate that changes in expression of class II MHC genes and associated antigen-processing genes may also be involved in the enhancement of luteal cell-stimulated $\mathrm{T}$ cell proliferation, and that processing of antigens by luteal cells may be altered near the time of luteal regression. Alteration of antigen processing within luteal cells could result in binding of a different repertoire of peptides to class II MHC molecules, allowing luteal cells to stimulate T cell activation during luteal regression. The hypothesis tested in the present study is that expression of either li or DM changes near the end of the estrous cycle. Due to observations in the initial portion of the present study, we wished to determine whether steady-state concentrations of $\mathrm{DM} \alpha$ and $\mathrm{DM} \beta \mathrm{mRNA}$ are regulated by luteinizing hormone $(\mathrm{LH})$ and $\mathrm{PGF}_{2 \alpha}$, the classic hormonal regulators of luteal function, or by TNF- $\alpha$, which is suspected to play a significant role in regulation of luteal function. We have also examined highly enriched cultures of luteal endothelial (CLENDO) cells for the presence of DM $\alpha$ and DM $\beta$ mRNA, to determine whether endothelial cells of the $\mathrm{CL}$ express the components of the class II MHC antigen-processing pathway.

\section{Materials and Methods}

\section{Reagents}

Powdered Ham's F-12 culture medium, gentamicin, fetal bovine serum, Escherichia coli DH5 $\alpha$ chemically competent cells, and TRIzol Reagent were all purchased from Life Technologies (Grand Island, NY, USA). Recombinant murine TNF- $\alpha$ was purchased from Life Technologies and R\&D Systems (Minneapolis, MN, USA). The National Hormone and Pituitary Program (Baltimore, MD, USA) provided bovine LH (NIAMMD-bLH-4). Insulin-transferrinselenium (ITS) premix was obtained from BD Biosciences (Bedford, MA, USA). Bovine serum albumin (fraction V), $\mathrm{PGF}_{2 \alpha}$, HEPES buffer and Bouin's fixative were purchased from Sigma. Prefer fixative was purchased from Anatech Ltd (Battle Creek, MI, USA). Type I collagenase was acquired from Worthington Biochemical Corp. (Freehold, NJ, USA). SDS and MOPS buffer were acquired from Amresco (Solon, OH, USA). Digoxigenin-labeled rNTP mix, alkaline-phosphatase-conjugated anti-digoxigenin Fab fragments, CDP-Star chemiluminescent substrate, blocking 
reagent, LightCycler-FastStart DNA SYBR Green I kits and ampicillin were all purchased from Roche. Random hexamer primers were purchased from Amersham. SuperScript II reverse transcriptase was acquired from Invitrogen. DyNAmo HS SYBR Green qPCR kits were purchased from MJ Research (Boston, MA, USA). Restriction enzymes, RNA polymerases, dNTPs, recombinant RNase inhibitor, Moloney murine leukemia virus $(M-M L V)$ reverse transcriptase, isopropyl- $\beta$-D-thiogalactopyranoside (IPTG) and 5-bromo-4-chloro-3-indolyl- $\beta$-Dgalactopyranoside (X-Gal) were purchased from Promega. Hybond $\mathrm{N}+$ membranes were obtained from Amersham Pharmacia Biotech (Piscataway, NJ, USA). Tissue culture flasks were from Corning (Acton, MA, USA). All other chemicals were purchased from Sigma or Fisher Scientific (Fairlawn, NJ, USA).

\section{Animals and tissue collection}

Multiparous, lactating dairy cows between 3 and 6 years of age were used in the present studies. Animals were housed indoors and had complete freedom of movement; they were given regular access to a total mixed ration and were allowed to feed ad libitum. Corpora lutea were removed transvaginally from regularly cycling dairy cows. Blood samples were collected from all animals prior to $\mathrm{CL}$ removal to determine circulating concentrations of progesterone. Corpora lutea were cut into four equal pieces, three of which were immediately snap frozen in liquid nitrogen, transported to the laboratory and stored at $-80^{\circ} \mathrm{C}$ until RNA extraction was performed. In the first experiment, $\mathrm{CL}$ were removed early in the estrous cycle (day $5, n=6$ ), during midcycle (days $9-12, n=6$ ) or late in the estrous cycle (day 18, $n=6$ ), or at $0.5(n=5), 1$ $(n=5), 4(n=5), 12(n=4)$ or $24 \mathrm{~h}(n=5)$ following i.m. administration of $25 \mathrm{mg} \mathrm{PGF} 2 \alpha$ (Lutalyse; Upjohn Co., Kalamazoo, MI, USA). In the second experiment, CL were removed during midcycle, immediately placed in ice-cold Ham's F-12 culture medium on ice and transported to the laboratory for dissociation. Handling of animals and surgical procedures were carried out in accordance with protocols approved by the Institutional Laboratory Animal Care and Use Committee of The Ohio State University.

\section{RNA isolation and Northern analysis}

Frozen tissue collected for the first experiment was homogenized in TRlzol reagent using a Polytron tissue homogenizer (Brinkman Instruments, Westbury, NY, USA). In the second experiment, RNA from cultured cells was isolated by adding TRIzol reagent directly to culture flasks. Following tissue homogenization or cell lysis, total cellular RNA was isolated according to procedures outlined by the manufacturer. The final RNA precipitate was resuspended in double-distilled water containing $0.1 \%$ diethyl pyrocarbonate (DEPC) and RNA concentration was determined spectrophotometrically.
Fifteen micrograms of total cellular RNA were electrophoretically separated on $1.5 \%$ agarose denaturing gels containing $20 \mathrm{mM}$ MOPS buffer, $5 \mathrm{mM}$ sodium acetate, $1 \mathrm{mM}$ EDTA and $0.66 \mathrm{M}$ formaldehyde. Following electrophoresis, gels were stained for $15 \mathrm{~min}$ with $1 \mu \mathrm{g} / \mathrm{ml}$ ethidium bromide in DEPC-treated water, destained for $1 \mathrm{~h}$ in DEPC-treated water and photographed. RNA was transferred to Hybond- $\mathrm{N}+$ membranes, and membranes were baked at $80^{\circ} \mathrm{C}$ for $2 \mathrm{~h}$ to crosslink RNA to the membranes. Gels were restained with eithidum bromide following transfer and examined under u.v. light to confirm complete transfer of RNA.

Digoxigenin-labeled riboprobes were synthesized using plasmids containing full-length Bovine Lymphocyte Antigen (BoLA)-DM $\alpha$, BoLA-DM $\beta$ or bovine class II MHCassociated li cDNA sequences. Plasmids containing these sequences have been described previously (Niimi et al. 1995, 1996) and were provided by Dr Yoko Aida (The Institute of Physical and Chemical Research, Tsukuba, Japan). Digoxigenin-labeled riboprobes were generated using linearized plasmids according to the instructions in Roche Molecular Biochemicals' DIG Nonradioactive Nucleic Acid Labeling and Detection System manual. Membranes were prehybridized at $68^{\circ} \mathrm{C}$ for $1 \mathrm{~h}$ with hybridization core buffer $(250 \mathrm{mM}$ sodium phosphate, $1 \mathrm{mM}$ EDTA, 5\% (w/v) SDS containing 0.5\% (w/v) Roche DIG Nucleic Acid Detection System Blocking Reagent), and hybridization was carried out for $16 \mathrm{~h}$ at $68^{\circ} \mathrm{C}$. Following hybridization, membranes were washed and detection was performed using alkaline phophatase-conjugated anti-digoxigenin Fab fragments in concert with the chemiluminescent CDP-Star substrate, according to the specifications in Roche Molecular Biochemical's DIG Nonradioactive Nucleic Acid Labeling and Detection System manual. Membranes were exposed to Biomax ML film (Eastman Kodak Co., Rochester, NY, USA) to detect chemiluminescence.

Quantification of steady-state concentrations of each message was performed densitometrically using a PDI 420oe scanning densitometer. The densitometric value (in arbitrary densitometric units) of the band of interest in each sample was standardized to the densitometric values of the corresponding $18 \mathrm{~S}$ rRNA.

\section{Luteal cell dissociation and culture}

Dissociation of luteal cells was carried out according to procedures described previously (Pate \& Condon 1982). Cell culture was performed in a humidified atmosphere of $5 \% \mathrm{CO}_{2}$ in air at $37^{\circ} \mathrm{C}$. Dispersed luteal cells $\left(4 \times 10^{6}\right.$ cells/flask) were cultured in Ham's F-12 medium supplemented with insulin $(5 \mu \mathrm{g} / \mathrm{ml})$, transferrin $(5 \mu \mathrm{g} / \mathrm{ml})$, selenium $(5 \mathrm{ng} / \mathrm{ml})$, gentamicin $(20 \mu \mathrm{g} / \mathrm{ml})$ and LH $(1 \mathrm{ng} / \mathrm{ml})$ in serum-coated $25 \mathrm{~cm}^{2}$ flasks, in a total of $4 \mathrm{ml}$ of culture medium. Cells were allowed to adhere overnight, medium was replaced and cultures were treated with $\mathrm{LH}$ $(10 \mathrm{ng} / \mathrm{ml}), \quad$ TNF- $\alpha(50 \mathrm{ng} / \mathrm{ml})$ or PGF $_{2 \alpha}(10 \mathrm{ng} / \mathrm{ml})$ in a 
$3 \times 3$ factorial arrangement. Treatment concentrations used in this study have been shown previously to affect function, viability and gene expression in cultured bovine luteal cells (Pate \& Condon 1984, Townson \& Pate 1994, Petroff et al. 2001, Cannon \& Pate 2003). Medium and treatments were replaced after $24 \mathrm{~h}$. Total RNA was extracted from cultured cells after $48 \mathrm{~h}$ of culture. The experiment was replicated a total of four times using $\mathrm{CL}$ from different animals.

\section{Isolation and culture of purified luteal endothelial cells}

Purified endothelial cells from bovine CL (CLENDO cells) collected during early pregnancy were purchased from Cambrex BioScience (BioWittaker, Walkersville, MD, USA) as described previously (Cavicchio et al. 2002, Pru et al. 2003, Liptak et al. 2005). In the present study, endothelial cells from frozen aliquots (passages 3-5; 5000 cells $/ \mathrm{cm}^{2}$ ) were cultured in EGM-2MV media, as recommended by the supplier with $3 \%$ fetal bovine serum (Cambrex Bioscience) in $60 \mathrm{~mm}$ dishes. Cultures were maintained at $37^{\circ} \mathrm{C}$ in a humidified atmosphere of $5 \%$ $\mathrm{CO}_{2}$ and $95 \%$ air. Culture medium was replaced every $48 \mathrm{~h}$ until $80-90 \%$ confluent. On the day of harvest, cells were equilibrated for $2-3 \mathrm{~h}$ in serum-free EBM-2 medium. CLENDO cells were collected in RLT lysis buffer and RNA was isolated using the RNeasy kit (Qiagen, Valencia, CA, USA) according to the manufacturer's specifications.

\section{Quantitative reverse transcription-PCR (RT-qPCR)}

Primers used to amplify DM $\alpha$ and DM $\beta$ cDNAs were designed based on the published sequences for DM $\alpha$ and DM $\beta$ (Niimi et al. 1995; GenBank accession numbers D76416 and D76417 respectively). Primer sequences were 5'-GCTCTCTGAGTCCTACGACGA-3' and 5'-GCACAGCACATTCTCCAGAAG-3' for DM $\alpha$ forward and reverse primers respectively, and 5'-CACCTGTGTGTTGGACGATGA-3' and 5'-AGCGTTACCAGAGCCACAGAA-3' for $D M \beta$ forward and reverse primers respectively. Amplification using DM $\alpha$ primers resulted in a single 526 bp DM $\alpha$ cDNA fragment, whereas amplification using DM $\beta$ primers resulted in a single $597 \mathrm{bp}$ DM $\beta$ cDNA fragment. Primer sequences used for amplification of steroidogenic acute regulatory protein (StAR) and CD31 (an endothelial cell adhesion molecule) mRNA in cultures of mixed luteal cells or luteal endothelial cells were based on the published sequences (Hartung et al. 1995, GenBank accession number NM_174189; Stewart et al. 1996, GenBank accession number U35433) and were as follows: 5'-CCTCTCTACAGCGACCAA-3' and 5'-TCGTGAGTGATGACCGTG-3' for StAR forward and reverse primers respectively; 5'-GTTCAGCGAAGTTCTGCGAG-3' and 5'-CTTGCTGGCTGTGGTCTTGT-3' for CD31 forward and reverse primers respectively. Amplification using the CD31 primers resulted in a 229 bp CD31 cDNA product and amplification using StAR primers yielded a $311 \mathrm{bp}$ StAR cDNA product. The identity of all PCR products was confirmed by DNA sequence analysis. An 854 bp glyceraldehyde-3-phosphate dehydrogenase (G3PDH) cDNA fragment was amplified in parallel reactions, using ovine specific primers described previously (Tsai et al. 1996), and concentrations of $D M \alpha, D M \beta, C D 31$ and StAR in each sample were standardized to the corresponding G3PDH concentrations.

Steady-state concentrations of mRNA encoding StAR, CD31, DM $\alpha$ and DM $\beta$ were determined in total RNA extracted from cultures of mixed luteal cells and luteal endothelial cells, using an MJ Research Opticon 2 realtime PCR thermal cycler. Prior to PCR, reverse transcription using random hexamer primers was performed on $2 \mu \mathrm{g}$ of total RNA extracted from cultures. PCR was then performed, using $200 \mathrm{ng}$ of reverse transcribed cDNA, using the DyNAmo HS SYBR Green qPCR kit according to the manufacturer's instructions. Thermal cycling was carried out using the following conditions: denaturation, $94{ }^{\circ} \mathrm{C}$ for $30 \mathrm{~s}$; annealing, $56^{\circ} \mathrm{C}$ for $30 \mathrm{~s}$; extension, $72{ }^{\circ} \mathrm{C}$ for $60 \mathrm{~s}$, for a total of 32 cycles. Melting curve analysis was performed after the end of the last cycle and, in conjunction with gel electrophoresis of amplified products, was used to verify the amplification of a single product in each sample. Fluorescence values in each tube were measured at the end of each cycle using single acquisition mode. Fluorescence values of the product of interest in each sample were standardized to the corresponding $\mathrm{G} 3 \mathrm{PDH}$ fluorescence values, and these standardized values were then used to calculate the mean steady-state amounts of each message. Since no standard curve was run for the messages of interest, values were expressed in arbitrary units of fluorescence for the purposes of analysis.

Steady-state concentrations of DM $\alpha$ and DM $\beta$ mRNA were determined in total RNA extracted from luteal cells treated with $\mathrm{LH}_{1} \mathrm{PGF}_{2 \alpha}$ and TNF- $\alpha$ using a Roche LightCycler real-time PCR thermal cycler. Prior to quantitative $\mathrm{PCR}, \mathrm{DM} \alpha, \mathrm{DM} \beta$ or $\mathrm{G} 3 \mathrm{PDH}$ reverse primer was used to reverse transcribe $200 \mathrm{ng}$ of total cellular RNA extracted from cultured cells. Quantitative PCR was then performed on $40 \mathrm{ng}$ of reverse transcribed RNA, using the Roche LightCycler-FastStart DNA Master SYBR Green I kit according to the manufacturer's instructions. As a standard curve, DM $\alpha, D M \beta$ and G3PDH cDNAs were amplified from lymph node total RNA, electrophoretically separated on a $1.2 \%$ agarose gel and eluted. The concentration of purified cDNA products was determined spectrophotometrically, and serial dilutions were prepared and used as an external standard curve in the quantitative PCR assays. Thermal cycling was carried out using the following conditions: denaturation, $94^{\circ} \mathrm{C}$ for $30 \mathrm{~s}$; annealing, $58^{\circ} \mathrm{C}$ for $30 \mathrm{~s}$; extension, $72^{\circ} \mathrm{C}$ for $60 \mathrm{~s}, 40$ cycles total. The ramping speed for transition from denaturation to annealing steps and annealing to extension steps was set manually at $1 \%$, while the ramping speed from extension to denaturation steps was set at $20 \%$ to minimize total running time. Melting curve analysis was performed after the end of the last cycle in order to verify the amplification of a single 
product in each sample. There was no evidence of primer dimers or bands other than the desired amplicons in the reactions as determined by melting curve analysis, and this was confirmed by gel electrophoresis of amplified products. The lack of undesired products allowed fluorescence measurements to be taken at the same temperature $\left(72{ }^{\circ} \mathrm{C}\right)$ at which extension was performed. Fluorescence values in each tube were measured at the end of each cycle using single acquisition mode. Samples were run in duplicate and fluorescence values for duplicate samples were averaged. The baseline fluorescence reading and noise band cut-off were set manually for samples and standards, in order to eliminate background fluorescence values from calculation of the slope and $y$-intercept of the standard curve. A standard curve was generated using average fluorescence values of duplicate standards. Average fluorescence values of samples were then used to calculate the concentration of target cDNA in each amplification reaction, using the Fit Points methods of the accompanying LightCycler data analysis software.

\section{Statistical analysis}

Normalized densitometric values collected from Northern analyses in the first experiment were subjected to twoway analysis of variance to determine whether differences in mean densitometric values of $D M \alpha, D M \beta$, or li RNA existed between stages of the estrous cycle. In the instance of a significant $F$ value, the Student-Newman-Kuels $(\mathrm{S}-\mathrm{N}-\mathrm{K})$ test was used to determine differences between specific means. Relative differences in steady-state concentrations of CD31, StAR, DM $\alpha$ and DM $\beta$ mRNA between cultures of mixed luteal cells or luteal endothelial cells were determined using Student's $t$ test. In the third experiment, steady-state concentrations of DM $\alpha$ or DM $\beta$ mRNA in treated luteal cell cultures were subjected to one-way ANOVA to determine if differences existed between treatment means. In the incidence of a significant $F$ value, the $\mathrm{S}-\mathrm{N}-\mathrm{K}$ test was used to determine differences between specific treatment means. Differences were considered to be significant at $P<0.05$. A $P$ value between 0.05 and 0.08 was considered to show a tendency towards a significant difference. All statistical procedures were performed using the SigmaStat statistical analysis software package (Jandel Corporation, San Rafael, CA, USA).

\section{Results}

The results of the Northern analyses to detect and quantify li, DM $\alpha$ and DM $\beta$ mRNA in luteal tissue are displayed in Figs 1 to 3 . Figure $1 \mathrm{~A}$ demonstrates the presence of an $\mathrm{li}$ transcript of approximately $1.3 \mathrm{~Kb}$ in all luteal tissue samples. Muscle tissue, which served as a source of negative control RNA, was devoid of any corresponding band (not shown). There was a large amount of variability
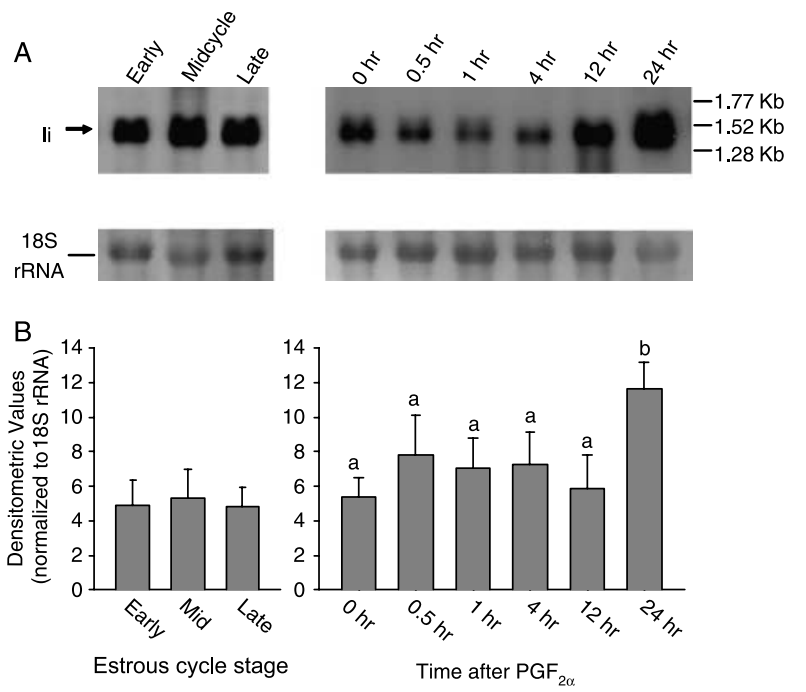

Figure 1 Northern analysis of li mRNA in bovine luteal tissue. (A) Northern blot showing li mRNA in a single CL collected from each of the following times of the estrous cycle: early (day $5, n=6$ ); during midcycle (days $10-12, n=6$ ); or late (day 18, $n=6$ ); and at $0(n=5), 0.5(n=5), 1(n=5), 4(n=5), 12(n=4)$ or $24 \mathrm{~h}(n=5)$ following administration of $25 \mathrm{mg} \mathrm{PGF}{ }_{2 \alpha}$ to the cow. 18S rRNA corresponding to each sample is also shown. (B) Steady-state concentration of li mRNA in luteal tissues collected at each time point (mean \pm S.E.M., $n$ values are as stated above). Bars represent densitometric values of li mRNA standardized to $18 \mathrm{~S}$ rRNA. Values with different letters are significantly different $(P<0.05)$.

among animals in the steady-state concentration of li mRNA following in vivo administration of $\mathrm{PGF}_{2 \alpha}$. This is responsible for the apparent discrepancy between the density of bands in the Northern blot shown in Fig. 1A and the graph shown in Fig. 1B, which represents the mean of data from four or five animals at each time after $\mathrm{PGF}_{2 \alpha}$ administration. There were no differences in concentrations of Ii mRNA between CL collected at any stage of the estrous cycle; however there was a greater than two-fold increase in steady-state concentrations of li mRNA in $\mathrm{CL}$ collected $24 \mathrm{~h}$ after $\mathrm{PGF}_{2 \alpha}$ administration $(P<0.05$, Fig. 1B). Figure 2A shows a Northern blot of $\mathrm{DM} \alpha \mathrm{mRNA}$ demonstrating the presence of a single DM $\alpha$ transcript in luteal tissue. Muscle tissue RNA was devoid of any corresponding band (not shown). Similar to the results of li Northern analysis, a large amount of variability among animals was also found in DM $\alpha$ mRNA concentrations following $\mathrm{PGF}_{2 \alpha}$ administration, which is responsible for the apparent difference between the density of bands in the Northern blot shown in Fig. 2A and the graph shown in Fig. 2B, which represents the mean of data from four or five animals at each time after $\mathrm{PGF}_{2 \alpha}$ administration. Such variability was not observed among animals in $\mathrm{CL}$ collected during the estrous cycle. Concentrations of DM $\alpha$ mRNA tended $(P>0.08)$ to be greater in $\mathrm{CL}$ collected during midcycle compared with $\mathrm{CL}$ collected early (day 5) or late (day 18) in the estrous cycle (Fig. 2B). There were no differences $(P>0.10)$ in concentrations of 

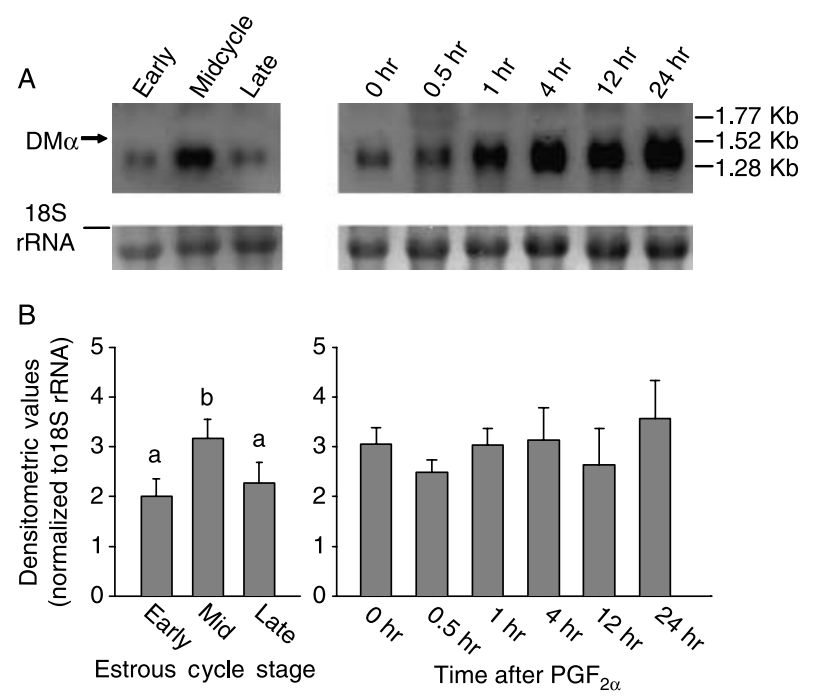

Figure 2 Northern analysis of DM $\alpha$ mRNA in bovine luteal tissue. (A) Northern blot showing DM $\alpha$ mRNA in a single $\mathrm{CL}$ collected from each of the following times of the estrous cycle: early (day $5, n=6$ ); during midcycle (days $10-12, n=6$ ); or late (day 18, $n=6$ ); and at $0(n=5), 0.5(n=5), 1(n=5), 4(n=5), 12(n=4)$ or $24 \mathrm{~h}(n=5)$ following administration of $25 \mathrm{mg} \mathrm{PGF}_{2 \alpha}$ to the cow. $18 \mathrm{~S}$ rRNA corresponding to each sample is also shown. (B) Steady-state concentrations of DM $\alpha$ mRNA in luteal tissues collected at each time point (mean \pm S.E.M., $n$ values are as stated above). Bars represent densitometric values of DM $\alpha$ mRNA standardized to $18 \mathrm{~S}$ rRNA. Values with different letters tended to be significantly different $(P<0.08)$.

DM $\alpha$ mRNA in CL collected following administration of a luteolytic dose of $\mathrm{PGF}_{2 \alpha}$, possibly due to the large degree of animal-to-animal variation mentioned earlier. Messenger RNA encoding $D M \beta$ was also detected in luteal tissue by Northern analysis, as demonstrated by the presence of a single $D M \beta$ transcript in all luteal tissue samples (Fig. 3A). Muscle tissue RNA was also devoid of any band corresponding to $D M \beta$ (not shown). Concentrations of DM $\beta$ mRNA were greater $(P<0.05)$ in midcycle $C L$ as compared with $\mathrm{CL}$ collected early or late in the estrous cycle (Fig. 3B), similar to DM $\alpha$. There were no differences in concentrations of $D M \beta$ mRNA following $\mathrm{PGF}_{2 \alpha}$ administration.

Steady-state concentrations of DM $\alpha$ and DM $\beta$ mRNA in CLENDO cells and mixed luteal cells were compared in order to determine whether endothelial cells derived from the bovine corpus luteum expressed $\mathrm{DM} \alpha$ and $\mathrm{DM} \beta$. Purity and composition of the CLENDO cell cultures and mixed luteal cell cultures was assessed using quantitative RT-PCR to determine steady-state concentrations of mRNA encoding CD31 and StAR protein. CD31 mRNA was present both in mixed luteal cell and CLENDO cultures, with much greater steady-state concentrations present in CLENDO cultures. StAR mRNA, while abundant in mixed luteal cell cultures, was undetectable in some CLENDO cultures, and was present in concentrations near the detection limit of the PCR assay in others (data not shown). Messenger RNA encoding $D M \alpha$ and $D M \beta$ was
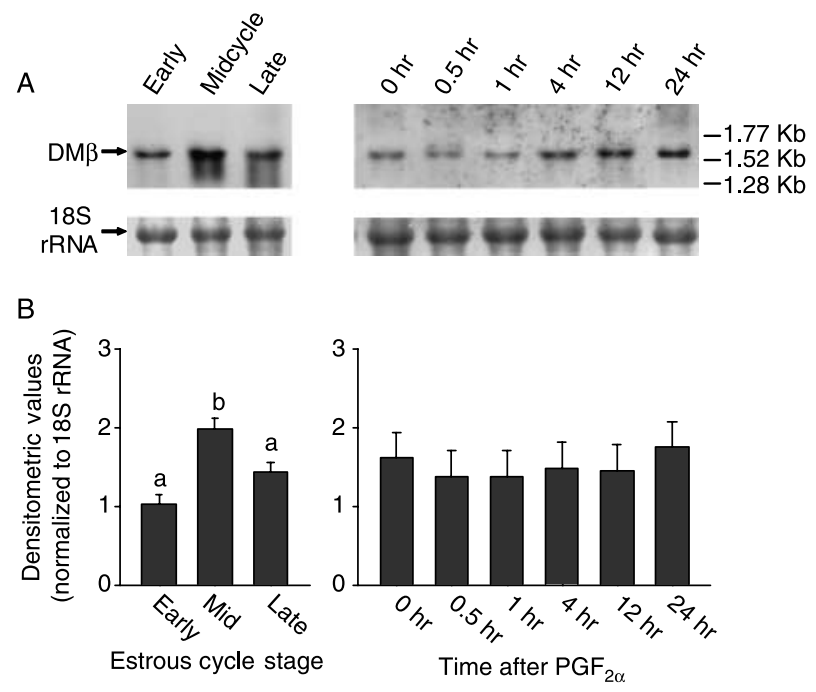

Figure 3 Northern analysis of DM $\mathrm{mRNA}$ in bovine luteal tissue. (A) Northern blot showing DM $\beta$ mRNA in a single CL collected from each of the following times of the estrous cycle: early (day $5, n=6$ ); during midcycle (days $10-12, n=6$ ); or late (day 18, $n=6$ ); and at $0(n=5), 0.5(n=5), 1(n=5), 4(n=5), 12(n=4)$ or $24 \mathrm{~h}(n=5)$ following administration of $25 \mathrm{mg} \mathrm{PGF}_{2 \alpha}$ to the cow. 18S rRNA corresponding to each sample is also shown. (B) Steady-state concentrations of DM $\beta$ mRNA in luteal tissues collected at each time point (mean \pm S.E.M., $n$ values are as stated above). Bars represent densitometric values of DM $\alpha$ mRNA standardized to $18 \mathrm{~S}$ rRNA. Values with different letters are significantly different $(P<0.05)$.

detectable in cultures of mixed luteal cells as well as CLENDO cell cultures. Steady-state concentrations of $D M \alpha$, but not $D M \beta$, mRNA were greater in CLENDO cultures (Fig. 4).

The effects of LH, PGF $2 \alpha$ and TNF- $\alpha$ on the concentrations of DM $\alpha$ mRNA in cultured bovine luteal cells are displayed in Fig. 5. Concentrations of DM $\alpha$ were less in TNF- $\alpha$-treated cultures compared with controls $(P<0.05)$. Similarly, in the presence of LH or PGF2 $\alpha$, TNF $\alpha$ caused a reduction in DM $\alpha$ mRNA concentrations. Treatment with TNF- $\alpha$ in the presence of both $\mathrm{LH}$ and $\mathrm{PGF}_{2 \alpha}$ also caused slight, but non-significant, reductions in $\mathrm{DM} \alpha$ mRNA. $\mathrm{LH}, \mathrm{PGF}_{2 \alpha}$ and TNF- $\alpha$ were all without effect on concentrations of BoLA-DM $\beta$ mRNA in cultured luteal cells (Fig. 5).

\section{Discussion}

The present study is the first to demonstrate the presence of mRNA encoding li, DM $\alpha$ and $D M \beta$ in the $C L$ of any species. These results are significant when considering the increase in the ability of luteal cells to stimulate $\mathrm{T}$ cell proliferation in response to $\mathrm{PGF}_{2 \alpha}$. Although we have previously demonstrated that reduction in progesterone synthesis is at least partly responsible for the increase in the ability of luteal cells to stimulate T lymphocyte proliferation following PGF $_{2 \alpha}$ administration (Cannon et al. 2003), alteration in intracellular antigen processing could 


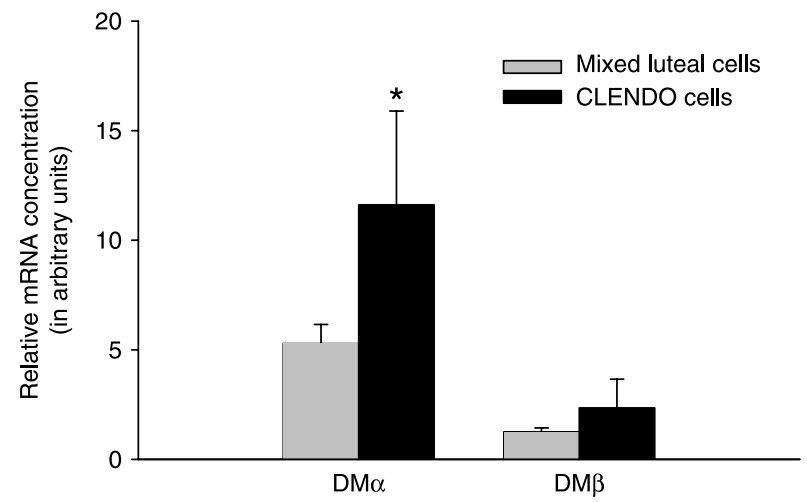

Figure 4 Steady-state concentrations of DM $\alpha$ and DM $\beta$ mRNA in cultures of mixed luteal cells and CLENDO cells. Bars represent concentrations of $\mathrm{DM} \alpha$ and $\mathrm{DM} \beta \mathrm{mRNA}$, as determined by RT-qPCR, in RNA extracted from cultures of mixed luteal cells (gray bars) or luteal endothelial cells (black bars) (mean \pm S.E.M., $n=3$ ). * Significant difference between mixed luteal cell and luteal endothelial cell cultures.
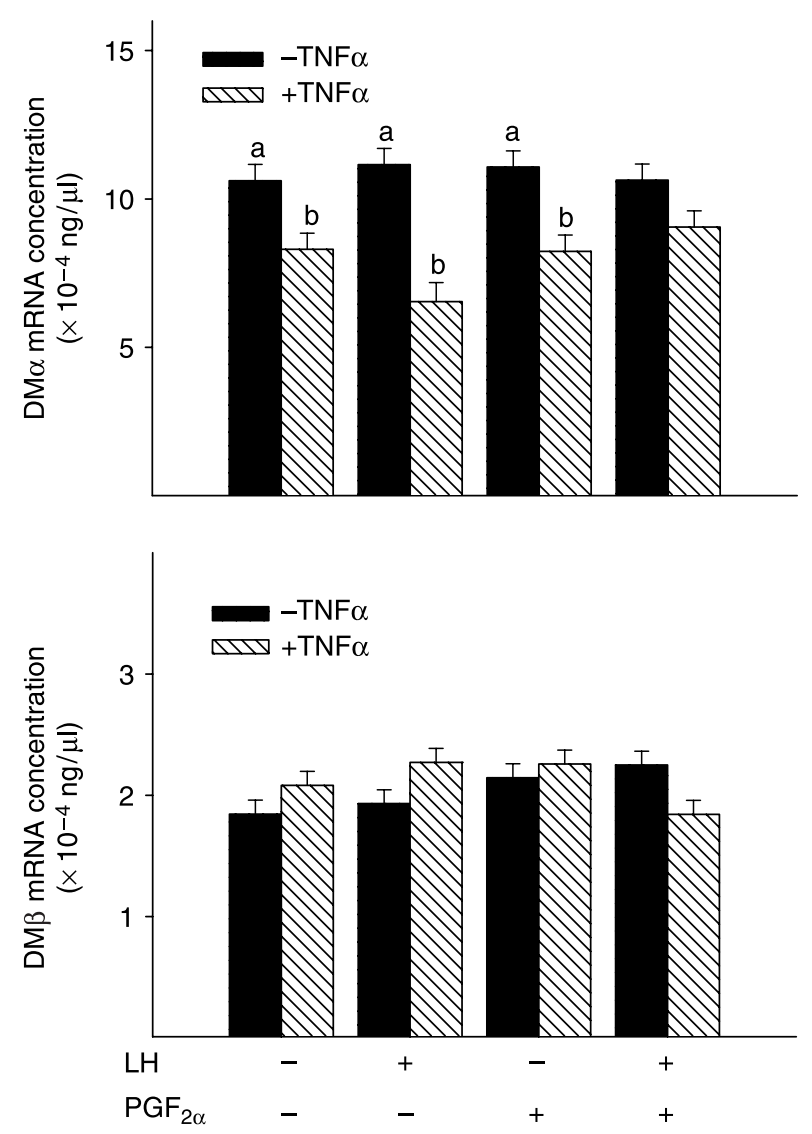

Figure 5 Steady-state concentrations of DM $\alpha$ mRNA (upper panel) and DM $\beta$ mRNA (lower panel) in cultures of mixed luteal cells. Bars represent concentrations of $\mathrm{DM} \alpha$ and $\mathrm{DM} \beta \mathrm{mRNA}$, as determined by RT-qPCR, in RNA extracted from luteal cells cultured in the presence or absence of $\mathrm{LH}$ and/or $\mathrm{PGF}_{2 \alpha}$, with (hatched bars) or without (black bars) TNF- $\alpha$. Different letters denote significant differences between cultures in the presence or absence of TNF- $\alpha$ (mean \pm S.E.M., $n=4$, $P<0.05)$. also contribute to the enhanced ability of luteal cells from regressing $C L$ to stimulate $T$ cell proliferation. Alterations in $D M \alpha$ and $D M \beta$ expression near the end of the estrous cycle could catalyze a change in luteal cells that facilitates the process of luteal regression.

Steady-state concentrations of li mRNA were not different at any stage of the estrous cycle. The reason for this is not clear. Class II MHC expression on bovine luteal cells increases throughout the estrous cycle and following PGF $_{2 \alpha}$ administration (Benyo et al. 1991), and since li is required for transport of class II MHC molecules to the cell surface, expression of li would be expected to parallel class II MHC expression. Given the observed lack of change in li mRNA during the estrous cycle or following administration of $\mathrm{PGF}_{2 \alpha}$, it appears that this gene is constitutively expressed in luteal tissue. It is possible that constitutive expression of $\mathrm{Ii}$ is sufficient to allow transport of class II MHC molecules to the cell surface. It must be noted, however, that the present study measured mRNA whereas the previous study measured cell surface proteins (Benyo et al. 1991). In that study, expression of class II $\mathrm{MHC}$ molecules by luteal cells was not measured beyond $12 \mathrm{~h}$ after a luteolytic dose of $\mathrm{PGF}_{2 \alpha}$. It is possible that class II MHC expression may increase dramatically by $24 \mathrm{~h}$ after $\mathrm{PGF}_{2 \alpha}$, similar to the increase in Ii mRNA concentrations observed in the present study.

Concentrations of DM $\alpha$ and $D M \beta$ mRNA were greatest in the $\mathrm{CL}$ during midcycle, and declined near the time of luteal regression. Since previous studies have shown that Ii and DM are coordinately regulated by the class II transactivating factor CIITA (Steimle et al. 1994, Chang \& Flavell 1995), this result was unexpected in light of the observed lack of change in li mRNA concentration throughout the estrous cycle. The number of bovine luteal cells expressing class II MHC molecules, as well as the degree of class II MHC expression, both increase near the time of luteal regression (Benyo et al. 1991). The decline in $\mathrm{DM} \alpha$ and $\mathrm{DM} \beta$ mRNA concentrations in luteal tissue concurrent with increases in class II MHC expression may result in presentation of a repertoire of peptides to $\mathrm{T}$ cells during luteal regression that is different from that presented during midcycle. Administration of a luteolytic dose of $\mathrm{PGF}_{2 \alpha}$ to the cow did not induce changes in the steady-state concentrations of DM $\alpha$ or DM $\beta$ mRNA. The reason for the lack of effect of $\mathrm{PGF}_{2 \alpha}$ on $\mathrm{DM} \alpha$ and $\mathrm{DM} \beta$ expression is unknown, but it is evident that the control of expression of these genes in the $\mathrm{CL}$ is not regulated by $\mathrm{PGF}_{2 \alpha}$. Treatment of cultured luteal cells with TNF- $\alpha$ reduced concentrations of DM $\alpha$, and elevation of TNF- $\alpha$ during luteal regression has been demonstrated (Ji et al. 1991, Shaw \& Britt 1995). Elevation of TNF- $\alpha$ in the $\mathrm{CL}$ was not observed until after the decline in circulating and tissue concentrations of progesterone, but intra-luteal concentrations of TNF- $\alpha$ may increase prior to the decline in circulating concentrations of progesterone, which would explain the decline in DM $\alpha$ mRNA observed in late cycle $\mathrm{CL}$. Steady-state concentrations of DM $\beta$ mRNA were not 
affected by $\mathrm{LH}, \mathrm{TNF}-\alpha$ or $\mathrm{PGF}_{2 \alpha}$ indicating that multiple factors control the expression of DM in the CL.

The present study demonstrates the presence of Ii, DM $\alpha$ and DM $\beta$ mRNA in luteal tissue in amounts detectable using the relatively non-sensitive method of Northern analysis. That these messages are detectable by Northern analysis is suggestive of a source of mRNA other than infiltrating macrophages and B lymphocytes, which are relatively few in number compared with the total number of cells in the bovine CL. DM $\alpha$ and DM $\beta$ mRNA were also found in CLENDO cultures in the present study, which provides support for the hypothesis that a cell type in addition to macrophages in the $\mathrm{CL}$ expresses these components of the antigen-processing pathway. It is worth noting that the CLENDO cultures used in the present study are composed of very highly purified populations of luteal endothelial cells, since the concentration of CD31 mRNA in CLENDO cells was approximately tenfold greater than in mixed luteal cell cultures, whereas StAR mRNA is almost undetectable. Conversely, the mixed luteal cell cultures contain largely steroidogenic cells, but are likely to also contain small numbers of endothelial cells; large amounts of StAR mRNA were present in the mixed luteal cell cultures, whereas concentrations of CD31 mRNA were much less than those in CLENDO cultures. Steady-state concentrations of DM $\alpha$ were greater in CLENDO cell cultures compared with mixed luteal cell cultures, and although it was not significant, concentrations of DM $\beta$ mRNA also appeared to be greater in CLENDO cell cultures compared with mixed luteal cell cultures. However, DM $\alpha$ and $D M \beta$ mRNAs were also present in mixed luteal cell cultures in relatively high abundance. From the analysis of CD31 concentrations in the CLENDO and mixed luteal cell cultures, we have concluded that endothelial cells make up a very small proportion of the total cells in mixed luteal cell cultures. Therefore, it seems unlikely that endothelial cells account for the relatively large amount of DM $\alpha$ and $D M \beta$ mRNA present in mixed luteal cell cultures. We have not assessed the presence of macrophages in these cultures, but while it is unlikely that macrophages are present in the CLENDO cultures, due to the purification procedures used to derive these cultures, it is possible that significant numbers of macrophages are present in mixed luteal cell cultures. This would account for the presence of the relatively large amount of $D M \alpha$ and $D M \beta$ mRNA found in mixed luteal cell cultures. It is unfortunate that it was not possible to obtain a pure population of steroidogenic luteal cells for these studies, and it is not possible to conclude from this experiment whether or not steroidogenic cells express $D M \alpha$ and $D M \beta$. However, these results clearly demonstrate that luteal endothelial cells express $\mathrm{DM} \alpha$ and $\mathrm{DM} \beta$.

In conclusion, the present study demonstrates the expression of $\mathrm{Ii}, \mathrm{DM} \alpha$ and $\mathrm{DM} \beta$ genes in luteal tissue. These genes encode intracellular antigen-processing proteins required for processing and presentation of antigenic peptides to T lymphocytes. The changes in $\mathrm{DM} \alpha$ and $D M \beta$ expression observed near the end of the estrous cycle could result in presentation of an altered repertoire of self-peptides in the context of class II MHC molecules. This alteration of antigen presentation may have significant implications for regulation of luteal function via interaction of resident $\mathrm{T}$ lymphocytes with cells of the $\mathrm{CL}$. However, since expression of the antigen-processing components examined in this study is greatest during midcycle, it is possible that presentation of antigen by class II MHC is necessary in the fully functional CL to maintain a state of immune tolerance to the tissue. Since immune tolerance would no longer be essential at the end of the estrous cycle, the decline in DM $\alpha$ and $\mathrm{DM} \beta$ expression may serve to facilitate activation of immune cells that may participate in the process of regression. Future studies are needed to determine the role(s) played by the immune system in regulation of luteal function.

\section{Acknowledgements}

The authors would like to thank Dr Yoko Aida for the generous gift of plasmids containing the bovine invariant chain, DM $\alpha$ and DM $\beta$ cDNA sequences, and also Jodi Winkler for technical assistance. This work was supported by NIH grants HD37550 to J L P and HD48754 to J S D. Salaries and research support were also provided by State and Federal funds appropriated. The authors declare that there is no conflict of interest that would prejudice the impartiality of this scientific work.

\section{References}

Avva RR \& Cresswell P 1994 In vivo and in vitro formation and dissociation of HLA-DR complexes with invariant chain-derived peptides. Immunity $1763-774$.

Bagavandoss P, Wiggins RC, Kunkel SC, Remick DG \& Keyes PL 1990 Tumor necrosis factor production and accumulation of inflammatory cells in the corpus luteum of pseudopregnancy and pregnancy in rabbits. Biology of Reproduction 42 367-376.

Bakke O \& Dobberstein B 1990 MHC class II-associated invariant chain contains a sorting signal for endosomal compartments. Cell $63707-716$.

Benyo DF \& Pate JL 1992 Tumor necrosis factor- $\alpha$ alters bovine luteal cell synthetic capacity and viability. Endocrinology 130 854-860.

Benyo DF, Haibel GK, Laufman HB \& Pate JL 1991 Expression of major histocompatibility complex antigens on the bovine corpus luteum during the estrous cycle, luteolysis, and early pregnancy. Biology of Reproduction 45 229-234.

Bodmer H, Viville S, Benoist C \& Mathis D 1994 Diversity of endogenous epitopes bound to MHC class II molecules limited by invariant chain. Science 263 1284-1286.

Brännström M, Giesecke L, Moore IC, van den Heuvel CJ \& Robertson SA 1994 Leukocyte subpopulations in the rat corpus luteum during pregnancy and pseudopregnancy. Biology of Reproduction $501161-1167$.

Cannon MJ \& Pate JL 2003 Expression and regulation of interferon $\gamma$-inducible proteasomal subunits LMP7 and LMP10 in the bovine corpus luteum. Biology of Reproduction 68 1447-1454.

Cannon MJ, Petroff MG \& Pate JL 2003 Effects of prostaglandin $F_{2 \alpha}$ and progesterone on the ability of bovine luteal cells to stimulate $T$ lymphocyte proliferation. Biology of Reproduction 69 695-700. 
Castellino F, Zhong G \& Germain RN 1997 Antigen presentation by MHC class II molecules: invariant chain function, protein trafficking, and the molecular basis of diverse determinant capture. Human Immunology 54 159-169.

Cavicchio VA, Pru JK, Davis BS, Davis JS, Rueda BS \& Townson DH 2002 Secretion of monocyte chemoattractant protein-1 by endothelial cells of the bovine corpus luteum: regulation by cytokines but not prostaglandin F2. Endocrinology 143 3582-3589.

Chang CH \& Flavell RA 1995 Class II transactivator regulates the expression of multiple genes involved in antigen presentation. Journal of Experimental Medicine 181 765-767.

Del Vecchio RP \& Sutherland WD 1997 Prostaglandin and progesterone production by bovine luteal cells incubated in the presence or absence of the accessory cells of the corpus luteum and treated with interleukin-1beta, indomethacin and luteinizing hormone. Reproduction, Fertility and Development 9 651-658.

Denzin LK, Hammond C \& Cresswell P 1996 HLA-DM interactions with intermediates in HLA-DR maturation and a role of HLA-DM in stabilizing empty HLA-DR molecules. Journal of Experimental Medicine 184 2153-2165.

Fairchild DL \& Pate JL 1991 Modulation of bovine luteal cell synthetic capacity by interferon-gamma. Biology of Reproduction $\mathbf{4 4}$ $357-363$.

Fling SP, Arp B \& Pious D 1994 HLA-DMA and -DMB genes are both required for $\mathrm{MHC}$ class II/peptide complex formation in antigenpresenting cells. Nature 368 554-558.

Gorospe WC, Hughes FM \& Spangelo BL 1992 Interleukin-6: effects on and production by rat granulosa cells in vitro. Endocrinology $1301750-1752$.

Hartung S, Rust W, Balvers M \& Ivell R 1995 Molecular cloning and in vivo expression of the bovine steroidogenic acute regulatory protein. Biochemical and Biophysical Research Communications 215 646-653.

Ji I, Slaughter RG, Ellis JA, Ji TH \& Murdoch WJ 1991 Analyses of ovine corpora lutea for tumor necrosis factor mRNA and bioactivity during prostaglandin-induced luteolysis. Molecular and Cellular Endocrinology $8177-80$.

Jo T, Tomiyama T, Ohashi K, Saji F, Tanizawa O, Ozaki M, Yamamoto R, Yamamoto T, Nishizawa Y \& Terada N 1995 Apoptosis of cultured mouse luteal cells induced by tumor necrosis factor-alpha and interferon-gamma. Anatomy Record 241 70-76.

Katz JF, Stebbins C, Appella E \& Sant AJ 1996 Invariant chain and DM edit self-peptide presentation by MHC II molecules. Journal of Experimental Medicine 184 1747-1753.

Kenny N, Herman JR, Barisas BG \& Roess DA 1991 Flow cytometric analysis of class I and II MHC antigens on ovine luteal cell types. In Signaling Mechanisms and Gene Expression in the Ovary,. Ed. G Gibori. New York: Springer-Verlag.

Khoury EL \& Marshall LA 1990 Luteinization of human granulosa cells in vivo is associated with expression of MHC class II antigens. Cell Tissue Research 262 217-224.

Komatsu K, Manabe N, Kiso M, Shimabe M \& Miyamoto H 2003 Changes in localization of immune cells and cytokines in corpora lutea during luteolysis in murine ovaries. Journal Experimental Zoology 296A 152-159.

Krusche CA, Vloet TD, Herrler A, Black S \& Beier HM 2002 Functional and structural regression of the rabbit corpus luteum is associated with altered luteal immune cell phenotypes and cytokine expression patterns. Histochemistry and Cell Biology 118 479-489.

Lawler DF, Hopkins J \& Watson DE 1999 Immune cell populations in the equine corpus luteum throughout the oestrous cycle and early pregnancy: an immunohistochemical and flow cytometric study. Journal of Reproductive Fertility 117 281-290.

Lightstone L, Hargreaves R, Bobek G, Peterson M, Aichinger G, Lombardi G \& Lechler R 1997 In the absence of the invariant chain, HLA-DR molecules display a distinct array of peptides which is influenced by the presence or absence of HLA-DM. PNAS 94 5772-5777.
Liptak AR, Sullivan BT, Henkes LE, Wijayagunawardane MPB, Miyamoto A, Davis JS, Rueda BR \& Townson DH 2005 Cooperative expression of monocyte chemoattractant protein 1 within the bovine corpus luteum: evidence of immune cell-endothelial cell interactions in a coculture system. Biology of Reproduction 72 1169-1176.

Lotteau V, Teyton L, Péléraux A, Nilsson T, Karlsson L, Schmid SL, Quaranta V \& Peterson PA 1990 Intracellular transport of class II MHC molecules directed by invariant chain. Nature 348 600-605.

Maric MA, Taylor MD \& Blum JS 1994 Endosomal aspartic proteinases are required for invariant chain processing. PNAS 91 2171-2175.

Marieke van Ham S, Gruneberg V, Malcherek G, Broker I, Melms A \& Trowsdale J 1996 Human histocompatibilty leukocyte antigen (HLA)-DM edits peptides presented by HLA-DR according to their ligand binding motifs. Journal of Experimental Medicine $\mathbf{1 8 4}$ 2019-2024.

Morris P, Shaman J, Attaya M, Amaya M, Goodman S, Bergman C, Monaco JJ \& Mellins E 1994 An essential role for HLA-DM in antigen presentation by class II major histocompatibility molecules. Nature 368 551-554.

Neuvians TP, Schams D, Berisha B \& Pfaffl MW 2004 Involvement of pro-inflammatory cytokines, mediators of inflammation, and basic fibroblast growth factor in prostaglandin $\mathrm{F}_{2 \alpha}$-induced luteolysis in bovine corpus luteum. Biology of Reproduction 70 473-480.

Niimi M, Nakai Y \& Aida Y 1995 Nucleotide sequences and the molecular evolution of the DMA and DMB genes of the bovine major histocompatibility complex. Biochemical and Biophysical Research Communications 217 522-528.

Niimi M, Nakai Y \& Aida Y 1996 Identification of bovine invariant chain (Ii) gene by nucleotide sequencing. Biochemical and Biophysical Research Communications 222 7-12.

Nothnick WB \& Pate JL 1990 Interleukin-1 $\beta$ is a potent stimulator of prostaglandin synthesis in bovine luteal cells. Biology of Reproduction 43 898-903.

Pate JL \& Condon WA 1982 Effects of serum and lipoproteins on steroidogenesis in cultured bovine luteal cells. Molecular and Cellular Endocrinology 28 551-562.

Pate JL \& Condon WA 1984 Effects of prostaglandin $F_{2 \alpha}$ on agonistinduced progesterone production in cultured bovine luteal cells. Biology of Reproduction 31 427-435.

Pate JL \& Nephew KP 1988 Effects of in vivo and in vitro administration of prostaglandin $\mathrm{F}_{2 \alpha}$ on lipoprotein utilization in cultured bovine luteal cells. Biology of Reproduction 38 568-576.

Penny LA, Armstrong D, Bramley TA, Webb R, Collins RA \& Watson ED 1999 Immune cells and cytokine production in the bovine corpus luteum throughout the oestrous cycle and after induced luteolysis. Journal of Reproductive Fertility 115 87-96.

Petroff M, Coggeshall KM, Jones LS \& Pate JL 1997 Bovine luteal cells elicit major histocompatibility complex class II-dependent T-cell proliferation. Biology of Reproduction 57 887-893.

Petroff MG, Petroff BK \& Pate JL 1999 Expression of cytokine messenger ribonucleic acids in the bovine corpus luteum. Endocrinology $1401018-1021$.

Petroff MG, Petroff BK \& Pate JL 2001 Mechanisms of cytokineinduced death of cultured bovine luteal cells. Reproduction 121 753-760.

Pru JK, Lynch MP, Davis JS \& Rueda BR 2003 Signaling mechanisms in tumor necrosis factor alpha-induced death of microvascular endothelial cells of the corpus luteum. Reproductive Biology and Endocrinology 117.

Riese RJ, Wolf PR, Bromme D, Natkin LR, Villadangos JA, Ploegh HL \& Chapman HA 1996 Essential role for cathepsin S in MHC class II-associated invariant chain processing and peptide loading. Immunity 4 357-366.

Roche PA \& Cresswell P 1990 Invariant chain association with HLADR molecule inhibits immunogenic peptide binding. Nature 345 615-618.

Sant AJ 1994 Endogenous antigen presentation by MHC class II molecules. Immunology Research 13 235-267. 
Shaw DW \& Britt JH 1995 Concentrations of tumor necrosis factor alpha and progesterone within the bovine corpus luteum sampled by continuous-flow microdialysis during luteolysis in vivo. Biology of Reproduction 53 847-854.

Steimle V, Siegrist CA, Mottet A, Lisowska-Grospierr B \& Mach B 1994 Regulation of MHC class II expression by interferon- $\gamma$ mediated by the transactivator gene CIITA. Science 265 106-109.

Stewart RJ, Kashour TS \& Marsden PA 1996 Vascular endothelial platelet endothelial adhesion molecule-1 (PECAM-1) expression is decreased by TNF-alpha and IFN-gamma. Evidence for cytokineinduced destabilization of messenger ribonucleic acid transcripts in bovine endothelial cells. Journal of Immunology 156 1221-1228.

Townson DH \& Pate JL 1994 Regulation of prostaglandin synthesis by interleukin-1 beta in cultured bovine luteal cells. Biology of Reproduction 51 480-485.

Townson DH \& Pate JL 1996 Mechanism of action of TNF- $\alpha$-stimulated prostaglandin production in cultured bovine luteal cells. Prostaglandins 52361 -373.

Townson DH, O'Connor CL \& Pru JK 2002 Expression of monocyte chemoattractant protein-1 and distribution of immune cell populations in the bovine corpus luteum throughout the estrous cycle. Biology of Reproduction 66 361-366.

Tsai S-J, Wiltbank MC \& Bodensteiner KJ 1996 Distinct mechanisms regulate induction of messenger ribonucleic acid for prostaglandin $(\mathrm{PG}) \mathrm{G} / \mathrm{H}$ synthase-2, $\mathrm{PGE}\left(\mathrm{EP}_{3}\right)$ receptor, and $\mathrm{PGF}_{2 \alpha}$ receptor in bovine preovulatory follicles. Endocrinology; 137 3348-3355.

Vogt AB, Arndt O, Hämmerling GJ \& Kropshofer H 1999 Quality control of MHC class II associated peptides by HLA-DM/H2-M. Seminars in Immunology $11391-403$.

Young JE, Friedman CI \& Danforth DR 1997 Interleukin-1及 modulates prostaglandin and progesterone production by primate luteal cells in vitro. Biology of Reproduction 56 663-667.

Received 29 July 2005

First decision 27 September 2005

Revised manuscript received 26 October 2005

Accepted 10 January 2006 